\title{
KINSHIP TERMINOLOGY IN WESTERN SLAVIC LANGUAGES BASED ON CORPORA ANALYSIS
}

\author{
JANA KOBZOVÁ \\ Department of Slavonic Studies, Faculty of Arts, Masaryk University, Czech Republic \\ KOBZOVÁ, Jana: Kinship terminology in Western Slavic languages based on \\ corpora analysis. Journal of Linguistics, 2019, Vol. 70, No 2, pp. 289 - 298.
}

\begin{abstract}
This paper is discussing kinship arrangements and more generally families of Western Slavs based on linguistic and corpora data. It is argued here that we can find correlation between lexicon and society, and that studying of lexicon can provide supportive data for society examination. In this paper we used corpora data that provides us with reliable information about lexicon that is truly used by speakers of Western Slavic languages and provided possible explanations for changes occurring in this part of vocabulary. Paper is divided into three main parts, one discussing relations between social reality and kinship terminology, while the second is discussing data from corpora. Third part is devoted to drawing conclusions.
\end{abstract}

Keywords: kinship terminology, corpora linguistics, social reality, family, Western Slavic languages

\section{INTRODUCTION}

Research in lexicology has experienced a great shift with evolution of language corpora. Linguists does not need to blindly believe in dictionaries and language atlases anymore - they can instantly explore the written or spoken language of specific era and find out more about the real usage of lexemes.

This is the case of this paper as well. Research in kinship terminology tends to stick to assumptions about stable character of this part of lexicon and does not explore the patterns of change. Based on the study of Western Slavic languages we must conclude that change is clearly visible in naming relatives in these languages and that further changes will follow in the future.

This paper is based on examination of language corpora of Slovak, Czech and Polish, and contrasting the results with the standard, inherited kinship-terminology lexicon. Languages are being put into contrast with the reconstructed Proto-Slavic language and with each other as well.

The aim here is to challenge traditional views of kinship terminology, to define parts of the lexicon that are most prone to change, and to outline possible future changes to it. Our starting assumption is that kinship terminology is being simplified 
in the modern era, based on the change of family (from multigenerational to nuclear) and society itself (increasing level of non-married couples, children born to such relations, increasing level of divorces and more).

Article is divided into three main parts, one focusing on connections between social reality and kinship terminology, while the second part discusses kinship terminology in Western Slavic languages in more detail. This second part is then divided into three subchapters, one devoted to ancestors, one to coeval relatives and one to descendants. The last chapter tries to draw conclusions.

\section{KINSHIP TERMINOLOGY AND SOCIAL REALITY}

If we want to contrast kinship terminology with social reality, we need to focus on the possible links between these two objects for a moment. Kinship terminology surely is very stable. Even a short look at the lexicon will show us many similarities between Indo-European languages (e.g. English mother, Slovak matka and Italian madre are very similar and can be traced to one Proto-Indo-European etymon). Even the general assumption among many linguists is that social reality is not mirrored in the language and therefore kinship terminology does not change with changed social conditions. As stated by Thomas R. Trautmann, "Joining the anthropological study of kinship terminology with a rich historical record leads us to think that the structures of kinship terminology may be very slow to change and resistant to effects of changed political, economic or social circumstance [...]." [1]

On the other hand, the fact that many of the terms used in kinship terminology are still evident in the modern Indo-European languages (and therefore are used for several thousand years), however, does not imply that these cannot change. Even the assumption that political, economic and social circumstance does not mirror in terminology is not enough. In fact, we can see many terms being replaced, deleted or even being added to the lexicon. The real question therefore is not whether this is happening, but how and why, and whether this is really linked to the changing social arrangements.

For example, in studying and reconstructing Proto-Indo-European society, we are left with no more than reconstructed language, where kinship terms play a significant role. According to J. P. Mallory and Douglas Q. Adams, "the reconstructed lexicon offers us our best hope of glimpsing the world of the speakers of Proto-Indo-European," [2] what might be the reason for some scientists giving a bigger credit to terminology when reconstructing society. Heinrich Hettrich agrees with this: "Therefore, if the PIE kinship terminology, or at least parts of it, can be reconstructed, we can also conversely expect to obtain some indication about the social organization of the speakers." [3] This utilitarian attitude is shared by author of this article as well, with two reservations. First, the gained data (in this case terminology systems) should not be viewed as the only source of society 
reconstruction (explanation), as there might be more reasons for terminology change than the change in society. We do believe, however, that this data can provide us with interesting theories that should be verified (or falsified) in next stages of research. Second, we should not expect the society to have immediate effect on the vocabulary. As said before, kinship terminology is very stable and therefore a change in society that would influence the terminology must be a major one that is ongoing for several generations. As said by Sergey Kullanda, to think that "kinship terms reflect synchronous social conditions [...] would be absurd." [4] Having in mind these two reservations, looking at the changed systems of Slavic kinship terminology might provide interesting insights into changing society patterns.

\section{KINSHIP TERMINOLOGY IN WESTERN SLAVIC LANGUAGES}

\subsection{Ancestors in Western Slavic languages}

There is not much in the terminology of parents and grandparents to prove changes in social structure of the areas in question - these languages follow the old Indo-European and later Proto-Slavic patterns. In the areas of parents, the only change can be traced in wide-spread usage of terms tato, táta, tata and derivations, their incidence in corpora however makes only up to one quarter of the less affectionate terms otec, ojciec.

Very interesting (even though not for social structure) is changing nature of Slovak and partly Polish to two-word descriptive terminology in case of grandparents. There is no evidence for distinguishing grandparents from mother's and father's side, even though it is assumed that there might have been such distinction in ProtoIndo-European [5], even if some authors do not agree [3]. The same tendency to two-word terminology is evident in godparent terminology as well as in naming stepparents. This outlines the tendency to replace zero-equation terms with descriptive ones, occurring in more areas, as will be seen below.

The closest relations and terminology used for them seems to be stable very much, however this changes significantly when we examine other relations more deeply. First, let us have a look at aunt and uncle terminology. Original Proto-Slavic terminology strictly distinguished gender of parent's sibling, consanguinity, as well as gender of the intermediator (agent of this relation). This combination would provide us with eight possibilities in total. In Proto-Slavic we reconstruct term *teta for both mother's and father's side, and possibilities for naming her husband are so diverse that we can expect early dissolution and regional specialization (but we do not assume there would be different names for father's sister's husband and mother's sister's husband if the term for both these sisters is the same). This undifferentiation in case of parent's sister causes there are only six terms available in this area of relation left for Proto-Slavic, including term for mother's brother $\left({ }^{*} u j b\right)$ and father's brother $\left({ }^{*}\right.$ stryjb), where names for their wives are clearly derived 
from these terms, what can still be evident in Western Slavic languages (e.g. stryná as a wife of strýc in Slovak).

Nonetheless, comparing theory to corpora evidence shows that this six-term strategy is not valid in Western Slavic languages in full anymore. Even though these languages are still aware of the terms (as can be seen in dictionaries and elsewhere), they might not be aware of the original meaning. As the Czech language clearly shows, the only used term for father's or mother's brother is strýc, as occurrence of ujec is less than $1 \%$ compared to strýc. Terms stryna and ujčina for their wives are marginal (we can expect term teta to spread to these meanings as well). On the other hand, the same is true for Slovak and Polish, but with the other term (originally meaning "mother's brother"). The share of stryj (Polish) and strýc (Slovak) is just $20 \%$ (in case of Polish) or 50\% (in case of Slovak) of the full naming capacity for this term (terms), while $w u j$ and $u j e c$ (and derivates) are clearly dominant. Derivates for naming wives of these uncles are marginal here as well. In naming parent's sister's husband, we can conclude, that all the specialized terms are disappearing from the vocabulary as well what might cause speakers to reach out to consanguineal terminology even for this affinal relation.

It is not of big surprise that simplification of kinship terms is ongoing in other fields as well. One of such fields is naming parents in law that originate in ProtoIndo-European and are reconstructed in Proto-Slavic as *svekry (for husband's father) and *tbstb (for wife's father, even though etymology is not clear [6]), while terms for husband's and wife's mother are again derived from the one for father.

Modern Western Slavic languages (as documented in language corpora) tend to simplify these terms to one term for both husband's and wife's father and one for such mother. As in the terminology for aunts and uncles, we can see, that even here the preferred term is not the same among all the examined languages. Slovak is particularly fond of terms svokor (masculine) and svokra (feminine), differing in this area from both Czech and Polish giving priority to tchán and teść (masculine) and tchyně and teściowa (feminine). Differences in usage of different terms are great in all three languages. Slovak test' and testiná does not have higher i.p.m. than 11 for both terms, while svokor and svokra have i.p.m. more than 2 for masculine form and more than 7 for feminine. Similar situation is in Polish, while in Czech the difference in favour of tchán and tchyně is even more significant.

Interesting part of vocabulary is without a doubt the one of stepparents. The changing society with increasing number of divorces and new partners of parents raises a question of naming new types of relations. This is well described by Ondrejkovič and Majerčíková, where among changes in natality, marriage and divorce rate and abortion rate several others are listed - changes in education and work patterns, self-reflexion of women, rising economic standard, liberalization, rationalization, technical advancement or social state system [7]. While terms as macocha 'stepmother' and otčim 'stepfather' are still applicable, new types of 
naming, based on description are gaining more weight. Simple two-word nevlastná matka and nevlastný otec are accompanied by more detailed description terms as nový partner mojej mamy 'new partner of my mother' and similar ones, mainly in cases where parent is not married to their new partner. As this is a new territory, it would be unreasonable to draw any conclusions at this time, however, it is useful to have this in mind. We will focus on more emerging terms connected with social changes in the last decades in the following chapters.

\subsection{Coevals in Western Slavic languages}

Again, there is not much evidence of change in the closest family terms (brother, sister). Although, a whole new world opens when we come to cousin terminology. As is generally perceived, the inconsistency in naming cousins among Slavic languages suggests that these terms were formed only after dissolution of Slavic unity. In Polish we can see ongoing change from descriptive terms (such as brat cioteczny/stryjeczny/wujeczny what is attitude like the one held in Serbian for example) to two gendered terms - kuzyn and kuzynka, obviously take-overs from other European languages (most probably French). Descriptive terms still make around $10 \%$ share of the capacity, but their potential is very low to expect a revival. Even though there are still slight traces of descriptive terms in Czech and Slovak, these are so small that we can perceive the process of change as finished in this area (preferred terms in both these languages are bratranec and sestrenica, sestrenice), therefore derived terms from names for brother and sister respectively.

All three languages in question share their attitude to naming siblings-in-law. Even though at least two terms of the terminology (PIE * daiwer- "husband's brother" and *jenater- "husband's brother's wife") are reliably reconstructed in Proto-Indo-European, and though these are still preserved e. g. in (some) Southern Slavic languages, all three examined Western Slavic languages replaced them again with two gendered terms (švagor a švagriná in Slovak, švagr and švagrová in Czech and szwagier and szwagierka in Polish), all clearly take-overs from German, as in f. e. Slovenian. All even despite the fact that we can see possibility of 10 relations names in total here (12 if we distinguish gender of the speaker: husband's brother and his wife, husband's sister and her husband, wife's brother and his wife, wife's sister and her husband, brother's wife and sister's husband from the point of woman or man). This great simplification is another important point in the research.

Before we get to naming husbands and wives, we would like to point to one quite rarely used term for children's partner's parents (svat or swat for such father and svatka or swatowa for such mother). Even though their usage is not very high (partly probably because of the distance of this relation), this is still a living part of the vocabulary in Western Slavic languages. This is especially important in the light 
of many terms disappearing and being replaced by descriptive ones around. For reasons that will need to be stated in future research, terms used for children's partner's parents seem to be more resistant than some others.

In naming one's partner, we again see a dynamically changing environment. Although names for legally wedded partners stay the same and there is no significant difference between the three Western Slavic languages, the changing society discussed above has an influence here as well. Terms that define not wedded partners, even living in one household and having children together (even though not necessarily) will need to be (re)invented. Official terms, such as Slovak druh and družka might be challenged by another terms as partner (partnerka), general muž 'man' and žena 'women' - possibly accompanied by possessive pronoun, or other terms. Whether they will be take-overs from another language, or we will witness semantic extension, will be decided in the future.

\subsection{Descendants in Western Slavic languages}

In case of closest family, the terms in Western Slavic languages seems to be untouched again. This is in compliance with the pattern already sketched above with parent and grandparent terminology, as well as sibling terminology. There is one standard term for both daughter, son, granddaughter and grandson, with only diminutives extending the basic vocabulary. All these terms are derived from ProtoSlavic and Proto-Indo-European respectively.

In case of naming partners of children, we cannot find any changes that would point to change of social arrangement. Even though all three languages stick to different terms for daughter-in-law (snacha in Czech, continuing the tradition, nevesta in Slovak, derived from bride-name, and synowa in Polish, deriving from name for son), there is no evidence of changing nature of these relations.

However, in the lateral line a great deal of simplification took place. Even though there are still some traces of distinguishing between brother's and sister's son and daughter in Czech and Slovak, these two languages adopted system of two gendered terms (synovec and neter or neter), even though each is of different origin (derivation from name for son and Proto-Indo-European origin). On the other hand, Polish still distinguishes all four types of relation (bratanek and bratanica, siostrzeniec and siostrzenica).

Finally, the topic of currently changing social conditions and naming partner's children from the previous marriages or relations is reflected in descendant line too. This is the field where descriptive terms gained a huge popularity and almost edged the original zero-equation term (pastorok and pastorkyña in Slovak, pastorek and pastorkyně in Czech). The only active part seems to be Polish, where pasierb and pasierbica are more frequent than descriptive terms. Interestingly, Polish (and surprisingly Czech) sticks to zero-equation terms also in case of godchildren, where Slovak has fully developed two-word descriptive terms. 


\section{CONCLUSIONS}

Our research has provided several outcomes that we would like to point to at this place. First, nuclear family terminology seems to be untouched and unchanged (terms for parents, grandparents, siblings, children and grandchildren). Second, in the lateral line (aunts and uncles, cousins, nephews) a great deal of simplification has taken place (except of nephew terminology in Polish). Third, affinal terminology seems to undergo different processes - the children-in-law and children's partner's parents terminology is untouched, in case of parents-in-law and siblings-in-law a major simplification has occurred, and in case of stepparents, stepchildren and partner names the situation became more complicated, mainly due to ongoing changes in the society that has not been finished yet.

Based on the corpora data, we can conclude that nuclear family, as the prevalent organization of family, has been natural in the areas of nowadays Poland, Czechia and Slovakia for a longer time that enabled change in the vocabulary. We can also conclude that extended family has lost part of its significance what enabled great deal of simplification of terminology. [8] This is also supported by the fact that some terms, previously reserved to consanguine relations only, are now used even for affinal relations. In the affinal relations, some simplification took place where possible - original inherited two gendered terms (for children-in-law and children's partner's parents) stayed untouched, whereas where there used to be more terms (parents-in-law and siblings-in-law) the simplification to two gendered terms is clearly visible.

Special area seems to be the one linked to current social changes (marriage, divorce, new partners etc.) where new terms are popping out regularly and we cannot predict which one will prevail yet.

When comparing attitudes of Western Slavic languages, all of them show similar patterns. However, Polish seems to be the most stable or even most conservative, what is shown on the nephew and children-in-law terminology. This opposes the general view of Polish as the most prone to branch away from fusional type of language [9], what should be characterized - among other things - by a rise of two-word descriptive terms.

It is thanks to language corpora data that we can outline Western Slavs societies here, as a simple search for the terms in dictionaries and in kinship terminology lists would not represent all the changes that we described above.

\section{Full data}

Table below does not include those terms that were not found in the corpora. In some places alternative meanings might be included (e.g. not just druh as one's partner, but also as "type") - these are in italic. Also, descriptive terms including more than two words are not included (e.g. nový partner mojej mamy). 
All the used corpora were accessed via Sketch Engine application, where the most recent and most extensive corpus was selected for each of the languages (Slovak Web 2011 - skenTen11, Czech Web 2017 - csTenTen17, Polish Web 2012 - plTenTen12) [10], [11].

\begin{tabular}{|c|c|c|c|c|c|c|}
\hline Term & Slovak & i.p.m. & Czech & i.p.m. & Polish & i.p.m. \\
\hline \multirow[t]{3}{*}{ Father } & otec & 230.63 & otec & 110.00 & ojciec & 192.6 \\
\hline & tato & 32.03 & táta & 23.88 & tata & 23.09 \\
\hline & tatino & 1.51 & tat'ka & 4.69 & tato & 20.12 \\
\hline \multirow[t]{7}{*}{ Grandmother } & stará mama & 3.32 & babička & 44.54 & babcia & 38.87 \\
\hline & stará matka & 0.37 & stařenka & 1.58 & staruszka & 4.82 \\
\hline & stará mat' & 0.24 & & & stara matka & 0.04 \\
\hline & babka & 21.5 & & & stara mama & 0.01 \\
\hline & babička & 8.97 & & & & \\
\hline & babina & 0.47 & & & & \\
\hline & starká & 3.41 & & & & \\
\hline \multirow[t]{4}{*}{ Grandfather } & dedko & 9.08 & děda & 12.91 & \begin{tabular}{|l} 
dziadek \\
\end{tabular} & 28.42 \\
\hline & dedo & 9.61 & dědeček & 10.44 & dziad & 5.66 \\
\hline & starý otec & 6.85 & děd & 5.57 & staruszek & 5.05 \\
\hline & starký & 2.39 & stařeček & 0.68 & stary ojciec & 0.13 \\
\hline \multirow[t]{3}{*}{ Aunt } & teta & 17.14 & teta & 12.85 & ciotka & 7.62 \\
\hline & stryná & 0.07 & stryna & $<0.01$ & stryjenka & 0.09 \\
\hline & ujčiná & 0.05 & ujčina & $<0.01$ & wujenka & 0.04 \\
\hline \multirow[t]{5}{*}{ Uncle } & strýko & 6.46 & strejda & 3.61 & stryj & 1.17 \\
\hline & strýc & 0.63 & strýc & 6.06 & stryjek & 0.34 \\
\hline & ujo & 12.00 & ujec & 0.07 & wuj & 1.93 \\
\hline & ujko & 0.41 & & & wujek & 7.16 \\
\hline & ujec & 0.51 & & & & \\
\hline \multirow[t]{2}{*}{ Father-in-law } & svokor & 2.04 & tchán & 2.23 & teść & 2.57 \\
\hline & test' & 0.11 & & & świekr & 0.01 \\
\hline \multirow{2}{*}{$\begin{array}{l}\text { Mother-in- } \\
\text { law }\end{array}$} & svokra & 7.68 & tchyně & 2.13 & teściowa & 7.4 \\
\hline & testiná & 0.07 & švekruše & $<0.01$ & świekra & 0.04 \\
\hline \multirow[t]{3}{*}{ Stepmother } & macocha & 1.26 & macecha & 0.91 & macochą & 0.18 \\
\hline & nevlastná matka & 0.09 & nevlastní matka & 0.21 & przybrana matka & 0.03 \\
\hline & nevlastná mama & 0.02 & nevlastní máma & 0.04 & & \\
\hline \multirow[t]{3}{*}{ Stepfather } & otčim & 0.47 & otčím & 0.50 & ojczym & 1.14 \\
\hline & nevlastný otec & 0.48 & nevlastní otec & 0.21 & przybrany ojciec & 0.05 \\
\hline & & & nevlastní táta & 0.02 & & \\
\hline \multirow[t]{3}{*}{ Godmother } & kmotor & 0.55 & kmotr & 9.81 & kum & 0.99 \\
\hline & krstný otec & 2.48 & křestní otec & $<0.01$ & kmotr & 0.01 \\
\hline & & & & & ojciec chrzestny & 2.06 \\
\hline \multirow[t]{3}{*}{ Godfather } & kmotra & 0.50 & kmotra & 1.81 & kuma & 0.79 \\
\hline & krstná mama & 0.39 & křestní matka & $<0.01$ & kmotra & $<0.01$ \\
\hline & krstná matka & 0.07 & & & matka chrzestna & 0.46 \\
\hline
\end{tabular}




\begin{tabular}{|c|c|c|c|c|c|c|}
\hline Term & Slovak & i.p.m. & Czech & i.p.m. & Polish & i.p.m. \\
\hline \multirow{4}{*}{$\begin{array}{l}\text { Cousin } \\
\text { (male) }\end{array}$} & bratranec & 5.35 & bratranec & 4.59 & brat cioteczny & 0.31 \\
\hline & strýčny brat & $<0.01$ & strýčenec & $<0.01$ & brat stryjeczny & 0.15 \\
\hline & & & tetěnec & $<0.01$ & brat wujeczny & 0.01 \\
\hline & & & & & kuzyn & 8 \\
\hline \multirow[t]{4}{*}{$\begin{array}{l}\text { Cousin } \\
\text { (female) }\end{array}$} & sesternica & 3.61 & sestřenice & 2.23 & \begin{tabular}{|l|} 
siostra \\
stryjeczna
\end{tabular} & 0.01 \\
\hline & strýčna sestra & $<0.01$ & tetěnice & $<0.01$ & siostra cioteczna & 0.12 \\
\hline & & & & & siostra wujeczna & $<0.01$ \\
\hline & & & & & kuzynka & 5.13 \\
\hline \multirow{2}{*}{$\begin{array}{l}\text { Co-parents- } \\
\text { in-law }\end{array}$} & svat & 1.25 & svat & 0.31 & swat & 0.91 \\
\hline & svatka & 0.09 & svatka & 0.30 & swatka & 0.19 \\
\hline \multirow{2}{*}{$\begin{array}{l}\text { Brother-in- } \\
\text { law }\end{array}$} & švagor & 2.89 & Švagr & 2.13 & szwagier & 4.05 \\
\hline & & & Švára & 0.14 & dziewierz & 0.01 \\
\hline \multirow[t]{3}{*}{ Sister-in-law } & švagriná & 1.44 & švagrová & 1.72 & szwagierka & 0.83 \\
\hline & švagrinka & 0.05 & zelva & 0.02 & jątrew & $<0.01$ \\
\hline & zolvica & 0.01 & & & & \\
\hline \multirow[t]{4}{*}{$\begin{array}{l}\text { Husband } \\
\text { (partner) }\end{array}$} & manžel & 91.89 & manžel & 93.93 & $\begin{array}{l}\text { moj/twoj/jej } \\
\text { mąż }\end{array}$ & 5.16 \\
\hline & môj muž & 5.71 & $\begin{array}{l}\text { můj/tvůj/ } \\
\text { její muž }\end{array}$ & 4.66 & małżonek & 8.36 \\
\hline & partner & 154.02 & partner & 114.79 & & \\
\hline & druh & 259.97 & druh & 273.79 & & \\
\hline \multirow[t]{4}{*}{$\begin{array}{l}\text { Wife } \\
\text { (partner) }\end{array}$} & manželka & 80.18 & manželka & 58.84 & $\begin{array}{l}\text { moja/twoja/ } \\
\text { jego żona }\end{array}$ & 11.76 \\
\hline & moja žena & 7.28 & $\begin{array}{l}\text { moje/tvoje/ jeho } \\
\text { žena }\end{array}$ & 8.65 & małżonka & 9.01 \\
\hline & partnerka & 13.37 & partnerka & 12.70 & & \\
\hline & družka & 2.07 & družka & 1.87 & & \\
\hline \multirow[t]{3}{*}{ Godson } & kmotrenec & $<0.01$ & kmotřenec & 0.11 & syn chrzestny & 0.01 \\
\hline & krstňa & 0.09 & & & chrześniak & 0.49 \\
\hline & krstný syn & 0.09 & & & & \\
\hline \multirow[t]{3}{*}{ Goddaughter } & kmotrenka & $<0.01$ & kmotřenka & 0.07 & córka chrzestna & 0.01 \\
\hline & krstná dcéra & 0.03 & & & chrześnica & 0.23 \\
\hline & & & & & chrześniaczka & 0.06 \\
\hline \multirow[t]{2}{*}{ Stepson } & pastorok & 0.45 & pastorek & 1.18 & pasierb & 0.65 \\
\hline & nevlastný syn & 0.23 & nevlastní syn & 0.10 & przybrany syn & 0.03 \\
\hline \multirow[t]{2}{*}{ Stepdaughter } & pastorkyňa & 0.12 & pastorkyně & 0.11 & pasierbica & 0.22 \\
\hline & nevlastná dcéra & 0.09 & nevlastní dcera & 0.26 & przybrana córka & 0.02 \\
\hline
\end{tabular}

Tab. 1. Full data used for this paper 
[1] Trautmann, T. R. (2001). The Whole History of Kinship Terminology in Three Chapters. Anthropological Theory 1(2), pages 268-287.

[2] Mallory, J. P., and Adams, D. Q. (2006) The Oxford Introduction to Proto-Indo-European and the Proto-Indo-European World. Oxford, Oxford University Press.

[3] Hettrich, H. (1985). Indo-European Kinship Terminology in Linguistics and Anthropology. Anthropological Linguistics 27(4), pages 453-480.

[4] Kullanda, S. (2002). Indo-European "Kinship Terms" Revisited. Current Anthropology, 43(1), pages 89-111.

[5] Friedrich, P. (1966) Proto-Indo-European Kinship. Ethnology 5(1), pages 1-36.

[6] Králik, L. (2016). Stručný etymologický slovník slovenčiny. Bratislava, Veda.

[7] Ondrejkovič, P., and Majerčíková, J. (2006). Zmeny v spoločnosti a zmeny v rodine - kontinuita a zmena. Slovak Sociological Review 38(1), pages 5-30.

[8] Parkin, R. (2015). Indo-European Kinship Terminologies in Europe: Trajectories of Change. Journal of the Anthropological Society of Oxford 7(2), pages 205-233.

[9] Lotko, E. (1986). Čeština a polština v překladatelské a tlumočnické praxi. Ostrava, Profil.

[10] Jakubíček, M. et al. (2013). The TenTen corpus family. In $7^{\text {th }}$ International Corpus Linguistics Conference CL 2013. Lancaster, 2013, pages 125-127.

[11] TenTen Corpus Family. Sketch Engine. Available at: https: / /www . sketchengi ne.eu. 